\section{Selcuk Journal of Agriculture and Food Sciences}

http://sjafs.selcuk.edu.tr/sjafs/index

Research Article

\section{SJAFS}

(2019) 33 (3), 223-226

e-ISSN: $2458-8377$

DOI:10.15316/SJAFS.2019.179

\title{
Some Reproductive Characteristics of Honamlı Goats
}

\author{
Hayri TOPBAŞ ${ }^{1, *}$, Birol DAĞ ${ }^{1}$ \\ ${ }^{1}$ Selçuk University, Faculty of Agriculture, Department of Animal Science, Konya, Turkey
}

\begin{tabular}{l}
\hline ARTICLE INFO \\
\hline Article history: \\
Received date: 09.05.2019 \\
Accepted date: 07.08.2019 \\
\hline Edited by: \\
Ibrahim AYTEKİ; Selçuk University, \\
Turkey \\
Reviewed by: \\
Mehmet KOYUNCU; Uluda ̌̆ \\
University, Turkey \\
Ali KARABAK; Selçuk University, \\
Turkey \\
\hline
\end{tabular}

\begin{abstract}
This study was carried out to investigate the some reproduction characteristics of Honamli goat breed that are rearing commonly in Taurus Mountains in the Mediterranean region of Turkey. The materials of the study was formed with the five years records from 2011 to 2016 of 27 flocks (average 220 bucks and 4400 does) chosen from 36 flocks within the scope of National Public Small Ruminant Improvement Project, which was raised under extensive conditions in Beyşehir and Derebucak districts of Konya. At the end of the research; kidding rate, survival rate, twin birth rate, fecundity, litter size and the averages for birth weight, weaning weight and daily weight gains for the five consecutive years were found as $85 \%, 87 \%, 15 \%, 0.94,1.10,3.64 \mathrm{~kg}, 19.14 \mathrm{~kg}, 0.180 \mathrm{~kg}$, respectively. Effects of farm, birth type and gender on live weights and daily weight gains were found to be statistically significant $(\mathrm{P}<0.01)$.
\end{abstract}

\author{
Keywords: \\ Konya \\ Reproductive characteristics \\ Honaml 1 \\ Goat \\ Birth weight
}

\section{Introduction}

The plenty number of the goat are constituting by the Hair goat (more than 90\%) in Turkey, and these are reared near the forested land. On the other hand, the Angora goats are composing $2.3 \%$ of the number of goats in Turkey, for the rests are constituting Norduz, Honaml, Malta, Kilis, Saanen, and some types of Hair goats. The breeds raised for milk production are Malta, Kilis and a tiny amount of Saanen goats and its crossbreeds which are becoming prevalent in west Anatolia. On the other hand, there were a tiny amount of some goats' breeds and different genotypes which adapted well into the different places in Turkey. This difference is providing an advantage in the search for productivity and improvement of our indigenous breeds.

The Honaml 1 goat is the breed that only raised in Taurus Mountains among Antalya, Burdur, and Konya, and takes attention for having products such as milk, meat, and fecundity. The most important sign of pureblooded Honaml 1 goats is $2 \mathrm{~cm}$ of distance between their horns. Their noses' frame is roman type (hooked). Dağ \& Zulkadir (2005) reported the mature live weights for bucks and does, litter size, birth weight for

\footnotetext{
${ }^{*}$ Corresponding author e-mail: hayri.topbas@hotmail.com
}

single and twins, lactation period, milk yield and hair yield as $80-95 \mathrm{~kg}, 50-70 \mathrm{~kg}, 1.8,3-4 \mathrm{~kg}, 2.5-3 \mathrm{~kg}, 270$ days, 135-216 $\mathrm{L}$ and 500-600 $\mathrm{g}$ respectively.

Honaml 1 goats are going to extinct like the other kind of goats because of some policies of the government that applied in the past such as; goats are destroying and giving harm to the forests. However, goats are both eating the greens that are not consumed by the other animals and they have transmuted them into meat and milk, then they are fertilizing the soil with their feces, and they prune the branches of the old trees which are close to the land by eating them. Furthermore, scrub is the land cover of the Taurus Mountains and that land cover has to be pruned, otherwise, it disappears and dries in 30 years. There are only some researches about these kinds of goats that are a very important local source of income for Turkey until today, pure breeding and the possibility of being distributed are going to down day by day because of hybridization with the other goats. Because of that reason, the breed characteristics should be determined by the researches for Honaml goats which are more productive for meat and milk according to the other kinds of goats in our country, these qualities should protect and use in scientific fields. From this point of view with this study, some reproductive traits of Honamlı goats are examined and it is thought that the findings obtained 
from this study will contribute to the identification of this breed and the subsequent studies.

\section{Materials and Method}

This study was carried out for 5 years between 2012 and 2016 within the scope of the National Public Small Ruminant Improvement Project in districts of Beyşehir (10 flocks) and Derebucak (17 flocks) of Konya province. The distribution of data collected from the 27 flocks remaining in the project for five years with an average of 4620 head goats (220 bucks and 4400 does) were given in Table 1.

Table 1

The Number of the goats and kids through the years

\begin{tabular}{ccccc}
\hline Years & $\begin{array}{c}\text { Breeding } \\
\text { does }\end{array}$ & Bucks & $\begin{array}{c}\text { Vivip- } \\
\text { arous } \\
\text { does }\end{array}$ & Weaned kids \\
\hline 2012 & 3200 & 200 & 2639 & 2124 \\
2013 & 5000 & 230 & 4204 & 4325 \\
2014 & 4650 & 225 & 3957 & 3736 \\
2015 & 4400 & 220 & 3770 & 3875 \\
2016 & 4750 & 225 & 4153 & 4091 \\
\hline Average & 4400 & 220 & 3744 & 3360 \\
\hline
\end{tabular}

The flocks of the study are grazing in open areas and forests from early morning until noon during the grazing season. Then the flocks are taken under any shadowy places at noon and rested in there because of decreasing grazing desire of goats due to the hot weather. In the afternoon, with the disappearance of the temperature stress factor, the grazing starts again in the mountainous forest areas and the flocks returns and is put into the shelters in the evening. In general, these regions vary in terms of pasture and forest quality and are available in high quality places where spruce, larch and oak trees are dense, as well as there are insufficient areas with the amount of pasture and quality of forest. Kids are nursed in the morning and in the evening and they are weaned at the age of 90 days. Young goats selected as breeder are put on to the forest land and non-breeder kids after weaning are sold until 120 days of age or they fatten up to the period of sacrifices festival to provide economic gain. For each year in this study; the records related to kid birth weight, gender, dam ear tag number, birth type, weaning weight (at 90 days) are kept and the averages such as kidding rate, survival rate, twin birth rate, fecundity, litter size, birth weight, weaning weight and daily weight gain were analyzed from these records by the years.

\section{Determination of goat reproductive traits}

Kidding rate $(\%)=$ Number of the viviparous does/Number of the breeding does

Twin birth rate $(\%)=$ Number of the does which gave birth to twins /Number of the viviparous does

Litter size $=$ The number of the newborn kids/ Number of the viviparous does
Fecundity $=$ The number of the newborn kids /Number of the breeding does

Survival rate $(\%)=$ The number of the living kids until the 90 days of age/the number of the live newborn kids

Weaning weight was determined at the day of 120 .

In 2012, but the other years it was determined in the 90. day. After the 90th day some of the kids are sold, that's why they didn't use for determining their survival rate.

\section{Determination of the kids' growth}

The kids were weighed and enumerated in the first 24 hours after birth. The birth weight of the kids, type of birth, gender and their mother ear tag numbers were registered. There were little amount of oak trees and spruces leafy branches given to the kids as forage during the suckling period in some farms. The kids' live weights at the weaning were weighed with precision scales. Weaning weights at the 90 days of age were calculated from the daily live weight gains by using interpolation method.

Statistical Analyses

General Linear Model (GLM) was used to determine the effect of birth type, farm and gender on live weight and growth. The following mathematical model was used to analyze the factors affecting the birth weight of the kids.

$$
Y_{i j k l m}: \mu+a_{i}+b_{j}+c_{k}+d_{1}+e_{i j k l m}
$$

Symbols of the models;

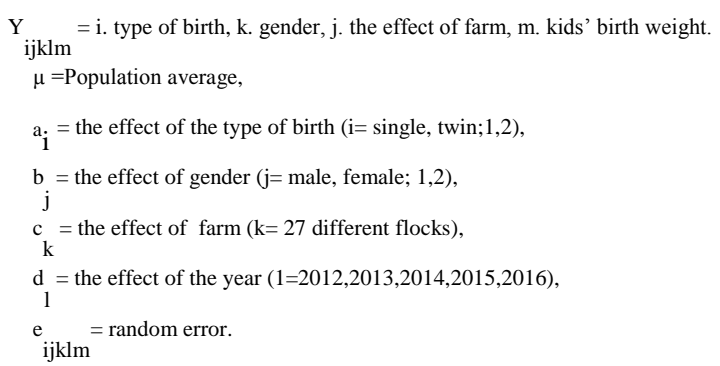

This model also was used for 90. days weight and daily live weight gain from birth to weaning by adding the regression of weaning weight according to birth weight;

$\mathrm{Y}_{\mathrm{ijklm}}=\mu+\mathrm{a}_{\mathrm{i}}+\mathrm{b}_{\mathrm{j}}+\mathrm{c}_{\mathrm{k}}+\mathrm{d}_{1}+\mathrm{b}_{1}\left(\mathrm{X}_{\mathrm{ijklm}}-\overline{\mathrm{x}}\right)+\mathrm{e}_{\mathrm{ijklm}}$

$\mu, a_{i}, b_{j}, c_{k}, d_{1}$ and $e_{i j k l m}$ are the same with the equation above,

$b_{1:}$ regression coefficient (partial regression of weaning weight according to birth weight)

$\mathrm{X}_{\mathrm{ijklm}}$ : i. type of birth, k. gender, j. the effect of farm, m. kids' birth weight, $\bar{x}$ : Average birth weight

Minitab package program was used for calculation (MINITAB, 2010).

\section{Results and Discussion}

Some fertility traits examined in the research flocks are given in Table 2. Kidding rate, survival rate, twin 
birth rate, fecundity, litter size, the birth weight, weaning weight and average daily weight gain were found as $85 \%, 87 \%, 15 \%, 0.94,1.10,3.64 \mathrm{~kg}, 19.14 \mathrm{~kg}, 0.180$ $\mathrm{kg}$, respectively. The differences between the years for the survival rates are found important $(\mathrm{P}<0.01)$.

Table 2

Some reproductive traits by the years

\begin{tabular}{cccccc}
\hline Years & $\begin{array}{c}\text { Kidding } \\
\text { rate } \\
(\%)\end{array}$ & $\begin{array}{c}\text { Survival } \\
\text { rate } \\
(\%)\end{array}$ & $\begin{array}{c}\text { Twin } \\
\text { birth } \\
\text { rate } \\
(\%)\end{array}$ & Fecundity & Litter size \\
\hline 2012 & $82 \%$ & $74 \%$ & $15 \%$ & 0.89 & 1.08 \\
2013 & $84 \%$ & $94 \%$ & $18 \%$ & 0.92 & 1.10 \\
2014 & $85 \%$ & $90 \%$ & $10 \%$ & 0.89 & 1.05 \\
2015 & $86 \%$ & $87 \%$ & $16 \%$ & 1.02 & 1.19 \\
2016 & $87 \%$ & $90 \%$ & $18 \%$ & 0.96 & 1.10 \\
\hline Mean & $85 \%$ & $87 \%$ & $15 \%$ & 0.94 & 1.10 \\
\hline $1: \chi^{2} \mathrm{P}<0.01$ & & & & &
\end{tabular}

Karadağ \& Soysal (2018) have stated in their study on the determination of some reproductive, growth and morphological characteristics of Honaml 1 goats, birth, infertility, single and twin birth rates were determined as $87 \%, 13 \%, 71 \%$ and $28 \%$, respectively. Litter size and fecundity were reported as 1.28 and 1.11 . They have stated the survival rate as $\% 80$ from birth to weaning. It seemed that similar studies in the same

Table 3

Birth and weaning weights and daily weight gains by the years breed goats have been found to have different fertility rates. The main reasons for the difference between twin birth rate, litter size and fecundity in the same breed may be explained the duration of the research (5 years), number of the materials, management, nutrition, flushing and the differences of regional climatic conditions.

Differences in the values of similar studies in goat breeds reveal breed differences and the birth rate compared to similar studies; Şengonca et al. (2003)'s Hair goats (79\%), Abbasoğlu (1998)'s Damascus goats (84.5\%), Ceyhan \& Karadağ (2009)'s Saanen goats $(81.7 \%)$ higher than their values, Karadağ \& Soysal (2018)' Honamlı Goats' (\%87), Keskin (1995)'s Hatay goats (\%94.3), Özcan (1977)'s Kilis goat (\%100) was found to be lower than the values were obtained.

The birth weight and weaning (90th day) live weights of kids were obtained by interpolation method and given in Table 3. Birth weight, weaning weight, and daily weight gain was $3.64 \mathrm{~kg}, 19.5 \mathrm{~kg}$, and 0.180 $\mathrm{kg}$, respectively, as the average of five years.

The differences in terms of farm, birth type and gender in mean live weights and average daily weight gains were found to be statistically significant ( $\mathrm{P}$ $<0.01)$.

\begin{tabular}{cccccc}
\hline Years & $\begin{array}{c}\text { Live born kids } \\
\text { number }\end{array}$ & $\begin{array}{c}\text { Average birth weight } \\
(\mathrm{kg})\end{array}$ & $\begin{array}{c}\text { Weaned kids } \\
\text { number }\end{array}$ & $\begin{array}{c}\text { Average weaning weight } \\
(\mathrm{kg})\end{array}$ & $\begin{array}{c}\text { Average daily weight gain } \\
(\mathrm{g})\end{array}$ \\
\hline 2012 & 2855 & $3.52 \pm 0.015^{\mathrm{C}}$ & 2124 & $17.24 \pm 0.100^{\mathrm{D}}$ & $0.152 \pm 0.0011^{\mathrm{E}}$ \\
2013 & 4612 & $3.61 \pm 0.011^{\mathrm{B}}$ & 4325 & $19.06 \pm 0.070^{\mathrm{C}}$ & $0.212 \pm 0.0008^{\mathrm{A}}$ \\
2014 & 4157 & $3.73 \pm 0.012^{\mathrm{A}}$ & 3736 & $18.90 \pm 0.075^{\mathrm{C}}$ & $0.169 \pm 0.0008^{\mathrm{D}}$ \\
2015 & 4472 & $3.63 \pm 0.012^{\mathrm{B}}$ & 3875 & $20.05 \pm 0.074^{\mathrm{B}}$ & $0.182 \pm 0.0008^{\mathrm{C}}$ \\
2016 & 4561 & $3.71 \pm 0.011^{\mathrm{A}}$ & 4091 & $20.43 \pm 0.072^{\mathrm{A}}$ & $0.186 \pm 0.0008^{\mathrm{B}}$ \\
\hline & 20657 & $3.64 \pm 0.005$ & 3630 & $19.14 \pm 0.035$ & $0.180 \pm 0.0004$ \\
\hline
\end{tabular}

A, B: $\mathrm{P}<0.01$

As can be seen from Table 4, a total of 20.657 goats used in this study, single and twin born kids' birth weights are given as $3.32 \mathrm{~kg}$ and $3.70 \mathrm{~kg}$, weaning weights were 18.45 and $19.49 \mathrm{~kg}$ and average daily live weight gains throughout suckling period were found

Table 4

Weaning weights through birth, sex, and birth type

\begin{tabular}{|c|c|c|c|c|c|c|}
\hline Traits & $N$ & Birth weight $(\mathrm{kg})$ & $N$ & Weaning weight $(\mathrm{kg})$ & \multicolumn{2}{|c|}{$N \quad A D L W G^{*}(\mathrm{~kg})$ (birth-90th day) } \\
\hline Birth type & & *** & & ** & & ** \\
\hline Twin & 3167 & $3.330 \pm 0.012^{B}$ & 2726 & $18.45 \pm 0.090^{B}$ & 2726 & $0.179 \pm 0.0009^{B}$ \\
\hline Single & 17490 & $3.706 \pm 0.0059^{A}$ & 15425 & $19.49 \pm 0.038^{A}$ & 15425 & $0.185 \pm 0.0004^{A}$ \\
\hline Sex & & ** & & ** & & ** \\
\hline Female & 10165 & $3.532 \pm 0.0074^{B}$ & 8919 & $17.97 \pm 0.043^{B}$ & 8919 & $0.169 \pm 0.0004^{B}$ \\
\hline Male & 10492 & $3.762 \pm 0.0078^{A}$ & 9232 & $20.65 \pm 0.052^{A}$ & 9232 & $0.197 \pm 0.0005^{A}$ \\
\hline
\end{tabular}

Regression coefficient (regression of weaning weight according to birth weight)

: $P<0.01 ;^{*}:$ Average daily live weight gain

Karadağ \& Soysal (2018) 's daily live weight gains in the period of sucking was $0.180 \mathrm{~kg}$ in twins and $0.205 \mathrm{~kg}$ in singles; birth weights 3.65 and $3.86 \mathrm{~kg}$ for male and female kids respectively. If the weaning weights of the present study adjusted for the 120th day, they were found to be lower than the values reported in the twins as $24.80 \mathrm{~kg}$ and $28.82 \mathrm{~kg}$ in the singles. The
0.179 and $0.185 \mathrm{~kg}$, respectively. In male and female kids' birth weights were $3.53 \mathrm{~kg}$ and $3.76 \mathrm{~kg}$, weaning weights were $17.97 \mathrm{~kg}$ and $20.65 \mathrm{~kg}$, and average daily live weight gains throughout suckling period were found to be $0.169 \mathrm{~kg}$, and $0.197 \mathrm{~kg}$ respectively. reason for this is that Karadağ \& Soysal's flock is a conservation herd and the breeding capability is made up of better animals, furthermore, the number of materials for our study is high and it can be explained as variable management conditions of 27 different flocks in a different pasture and forest quality under variable climatic conditions for five years. 
Differences in the values of similar studies performed in goat breeds reveal breed differences and the present study when compared with similar studies Şimşek et al. (2007) for the birth weight of Saanen X Hair goat $F_{1}$ and $G_{1}$ Hybrids 2.18 and $2.82 \mathrm{~kg}$, respectively; and for the weaning weights 14.07 , and 15.62 $\mathrm{kg}$; 0.131 for daily live weights gains during the suckling period, and again; Şimşek \& Bayraktar (2006) reported the average birth weights lower than this study as $2.77 \mathrm{~kg}$ and $2.95 \mathrm{~kg}$ for Hair Goat and Saanen X Hair Goat (F1) hybrids respectively.

Tuncel (1977) revealed the birth weights and weaning weights of Saanen X Kilis hybrids dairy goats (Akkeçi) as $3.1 \mathrm{~kg}$ and $15.8 \mathrm{~kg}$, respectively and Cengiz et al. (1982) reported Saanen X Kilis hybrids' weights at birth and 3 months of age as $2.96 \mathrm{~kg}, 15.14$ $\mathrm{kg}$ and they revealed the daily growth rate from birth to weaning as $138.2 \mathrm{~g}$. In a similar study, Özcan \& Güney (1983) reported the average birth weights of Damascus goats in single-born females, single-born males, twins born females, twins born males $4.0 \mathrm{~kg}, 3.45 \mathrm{~kg}, 3.90$ $\mathrm{kg}, 3.75 \mathrm{~kg}$ and weaning weights with the same row were found as $13.6 \mathrm{~kg}, 12.0 \mathrm{~kg}, 8.83 \mathrm{~kg}, 10.05 \mathrm{~kg}$ respectively. Although the values obtained for birth weight in Honamlı kids have been found to be lower than those of Damascus kids, weaning weights were found to be higher than the values reported above.

\section{Result and Conclusion}

In this study, some reproductive traits of Honaml goats that is one of the local genetic resources were examined. Although the values of fertility are generally affected by factors such as; breed, age, management, nutrition and regional conditions, the results that obtained from findings of this study are important because of being limited studies on this breed.

When the data obtained from this study were evaluated; in the terms of productive performance and growth characteristics, the use of Honamli goat breed, which have superior characteristics than other domestic goat breeds will contribute to the studies about meat and dairy goat breeding in our country. It can be said that genetic heritage should be protected due to its being.

\section{Acknowledgments}

The data of the study were obtained from "National Small Ruminant Breeding Project" carried out under the coordination of Directorate General of Agricultural Research and Policy of Republic of Turkey Ministry of Agriculture And Forestry with official approval.

Approval date and number: 17.05.2018/92190712604.02-E. 1483850

\section{References}

Abbasoğlu S (1998). A Research on the Reproduction and Milk Yield Characteristics of Damascus Goats Raised in a Güzelyurt State Production Farm in the Turkish Republic of Northern Cyprus. Çukurova University, Institute of Science and Technology. Balcalı / Adana

Cengiz F, Aşkın Y, Tuncel E (1982). Effects of Some Environmental Factors on Live Weight, Live Weight Gain and Body Properties of Saanen and Kilis Crossbred Milk Type Goats. Ankara University, Faculty of Agriculture Yearbook (30) 3-4 Separate Press, Ankara. (in Turkish)

Ceyhan A, Karadağ O (2009). Some Descriptive Characteristics of Saanen Goats Raised in Marmara Animal Husbandry Research Institute. Journal of Agricultural Sciences 15 (2): 196-203.

Dağ B, Zulkadir U (2005). Goat Husbandry and Improvement in Konya Province. Journal of Konya Commodity Exchanges 8 (19):40-45. (in Turkish)

Karadağ O, Soysal Mİ (2018). The Determination of Some Reproduction, Growth and Morphological Traits in Honamlı Goats Breed, Journal of Tekirdağ Agricultural Faculty 15 (01):135-142.

Keskin M (1995). Some Morphological and Physiological Characteristics of Goats Raised in Hatay Region. Master's Thesis. M.K.Ü. Graduate School of Natural and Applied Sciences, Department of Animal Science.

Minitab (2010). Minitab 16.1.1 for Windows. State College, PA, USA: Minitab Inc.

Özcan L, Güney O (1983). A Research on the Some Yields of Damascus Goats under Çukurova Region Conditions. Çukurova University Faculty of Agriculture Yearbook 14 (1): 12-27. Balcalı / Adana

Özcan L, Pekel E, Güney O (1976). Comparative Studies on Reproductive and Milk Yield Characteristics of Kilis, Hair and $\mathrm{GS}_{1}$ Goats Raised in Faculty of Agriculture of Çukurova University. Printing House of Agricultural Faculty of Ankara University

Özcan L (1977). Utilization of Saanen and $G_{1}$ Genotypes for the improvement of Kilis and Hair Goats Raised in Çukurova University, Faculty of Agriculture. Çukurova University, Faculty of Agriculture Pub. No: 122, Adana. (in Turkish)

Şengonca M, Taşkın T, Harness N (2003). A Simultaneous Study on Determination of Some Yield Characteristics of Saanen X Hair Goat Crossbreds and Purebred Hair Goats. Turk J Vet Anim Sci 27: 1319-1325

Şimsek ÜG, Bayraktar M (2006). Investigation of growth and survival characteristics of Hair goat and Saanen x Hair goat $\left(\mathrm{F}_{1}\right)$ hybrids Firat University Journal of Health Sciences 20 (3): 229-238. (in Turkish)

Şimşek ÜG, Bayraktar M, Gürses M (2007). Investigation of Growth and Survivability Characteristics in Saanen $\mathrm{x}$ Pure Hair Goats Crossbreeds $\mathrm{F}_{1}$ and $\mathrm{B}_{1}$. Firat University Journal of Health Sciences 21 (1): 21 - 26.

T. C. Ministry of Forestry, Water Affairs (2018). Upper Basin Flood Control Action Plan 2013-2017, General Directorate for Combating Desertification and Erosion, http://www.cem.gov.tr/erozyon/Files/EylemPlan/SEL\%2 0EYLEM\%2018subat.pdf [Visits date: 02 December 2018]

Tuncel E (1977). Some Crossing Experiments For Developing A New Dairy Goat in Turkey. Symposium on Goat Breeding in Mediterranean Countries. Malaga GranadaMurcia (Spain) 3rd-7th October 197. 